University of Nebraska - Lincoln

DigitalCommons@University of Nebraska - Lincoln

1980

\title{
Teleseismic Evidence for a Low-Velocity Body Under the Coso Geothermal Area
}

P. Reasenberg

U.S. Geological Survey

W. Ellsworth

U.S. Geological Survey

A. Walter

U.S. Geological Survey

Follow this and additional works at: https://digitalcommons.unl.edu/usgsstaffpub

Part of the Earth Sciences Commons

Reasenberg, P.; Ellsworth, W.; and Walter, A., "Teleseismic Evidence for a Low-Velocity Body Under the Coso Geothermal Area" (1980). USGS Staff -- Published Research. 384.

https://digitalcommons.unl.edu/usgsstaffpub/384

This Article is brought to you for free and open access by the US Geological Survey at DigitalCommons@University of Nebraska - Lincoln. It has been accepted for inclusion in USGS Staff -- Published Research by an authorized administrator of DigitalCommons@University of Nebraska - Lincoln. 


\title{
Teleseismic Evidence for a Low-Velocity Body Under the Coso Geotnermal Area
}

\author{
P. Reasenberg, W. Ellsworth, and A. Walter
}

U.S. Geological Survey, Menlo Park, California 94025

\begin{abstract}
Teleseismic $\boldsymbol{P}$ wave arrivals were recorded by a dense array of seismograph stations located in the Coso geothermal area, California. The resulting pattern of relative residuals reveals an area showing approximately 0.2 -s excess travel time that migrates with changing source azimuth, suggesting that the area is the 'delay shadow' produced by a deep, low-velocity body. Inversion of the relative residual data for three-dimensional velocity structure determines the lateral variations in velocity to a depth of $22.5 \mathrm{~km}$ beneath the array. An intense low-velocity body, which coincides with the surface expressions of late Pleistocene rhyolitic volcanism, high heat flow, and hydrothermal activity, is resolved between 5- and 20$\mathrm{km}$ depth. It has maximum velocity contrast of over $8 \%$ between 10 and $17.5 \mathrm{~km}$. The shallowest part of this body is centered below the region of highest heat flow; at depth it is elongate in approximately the N$S$ direction. The hypothesis that this low-velocity body is caused by the presence of partial melt in the middle crust is consistent with the local seismic, geologic, and thermal data.
\end{abstract}

\section{INTRODUCTION}

Analysis of teleseismic $\boldsymbol{P}$ waves recorded above geothermal systems has proven to be an effective method of determining the seismic properties of the underlying crust and upper mantle. A model of the seismic velocity structure provides useful constraints on the compositional and physical states of the geothermal system at depth. Teleseismic $P$ wave delays have been used extensively to infer velocity structure at several geothermal systems, including The Geysers, California [Steeples and Iyer, 1976a; Iyer et al., 1979], Yellowstone, Wyoming [Iyer, 1975; Iyer and Stewart, 1977; Zandt, 1978; Iyer, 1979], Long Valley, California [Steeples and Iyer, 1976b], and Kilauea Volcano, Hawaii [Ellsworth and Koyanagi, 1977].

In this paper the three-dimensional velocity structure under the Coso Range geothermal area, southern California, is studied using the $\boldsymbol{P}$ phases of steeply incident teleseismic waves. Lateral variations in velocity are estimated from observed $P$ wave delays both by simple modeling employing ray tracing (the forward problem) and by the single-step three-dimensional inversion technique described by $A$ ki et al. [1977].

The data are derived from approximately 5-km-wavelength plane compressional waves recorded by an array of sensors $\sim 25 \mathrm{~km}$ in diameter with station spacing approximately $5 \mathbf{k m}$ in the center of the array (Figure 1 and Table 1). The array covers the area of Pleistocene rhyolite domes below the central portion of which the existence of a centralized magma reservoir has been proposed [Bacon et al., 1980]. $P$ wave velocity in the proposed reservoir is expected to be abnormally low if magma or partially molten rock is currently present. With the collected suite of teleseismic data the three-dimensional inversion technique allows modeling of velocity structure in the volume beneath the array to a depth of $25 \mathrm{~km}$ with lateral resolution of approximately $5 \mathrm{~km}$.

\section{DESCRIPTION OF THE SEISMIC ARRAYS}

The U.S. Geological Survey (USGS) installed a network of 16 telemetered seismic stations in the Coso Range during September 1975 (Figure 1 and Table 1). This network was designed to provide continuous data for microearthquake studies and for teleseismic $\boldsymbol{P}$ wave delay studies. The network consisted of vertical geophones, seismic amplifiers, and telem-

This paper is not subject to U.S. copyright. Published in 1980 by the American Geophysical Union.

Paper number 9B0930. etry electronics conforming to the USGS central California network station specifications [Bufe et al., 1975]. Recording was done at Menlo Park, California, on a photographic film recorder. One hundred thirty-seven teleseismic events; suitable for $\boldsymbol{P}$ wave delay study, were recorded from September 28, 1975, to May 9, 1976 (Table 2), and are referred to as the permanent network data.

During May and June 1977 the U.S. Geological Survey operated a portable seismic array (Centipede) in the Coso region (Figure 1 and Table 1). The array consisted of 25 1.0-Hz vertical geophones. For additional stations (RCW, HWS, CBH, and VPE) belonging to the Coso permanent network were recorded by both systems. Seismic amplifiers and telemetry electronics of the Centipede stations are described by Reasenberg [1977]. The instrument response of the Centipede stations is nominally the same as that of the Coso permanent network. Recording was on a portable magnetic tape recorder located at Sugarloaf Mountain. Seven teleseismic events recorded during the 9 weeks of network operations were suitable for analysis and are referred to as the Centipede network data (Table 3).

\section{METhOD of DATa Reduction AND ANALYSIS}

The data considered in this study are the variations in the relative travel time between individual sensors as observed for steeply incident teleseismic $\boldsymbol{P}$ waves. These data are formed by differencing a predicted phase arrival time with arrival times measures on the seismograms. Relative travel time data for a dense, small-aperture network like the Coso array in essence map the cumulative phase distortion of the wave front created by its passage through heterogeneous structure encountered along its travel path. It is these relative delays in the wave front that are of central interest here and will be used to infer the presence (or absence) of lateral variations in velocity beneath the seismograph array.

Measurements of $P$ wave travel times. Travel times for the permanent network data were determined visually by measuring the arrival time of the first peak and/or zero crossing of the $P$ wave train. The uncertainty in timing clear arrivals is estimated to be better than $0.05 \mathrm{~s}$. Arrival times for the Centipede network data were obtained by phase correlation of the $P$ wavelets, as suggested by Press and Biehler [1964]. These measurements were made using an interactive computer program described by Reasenberg [1978]. The principal advan- 


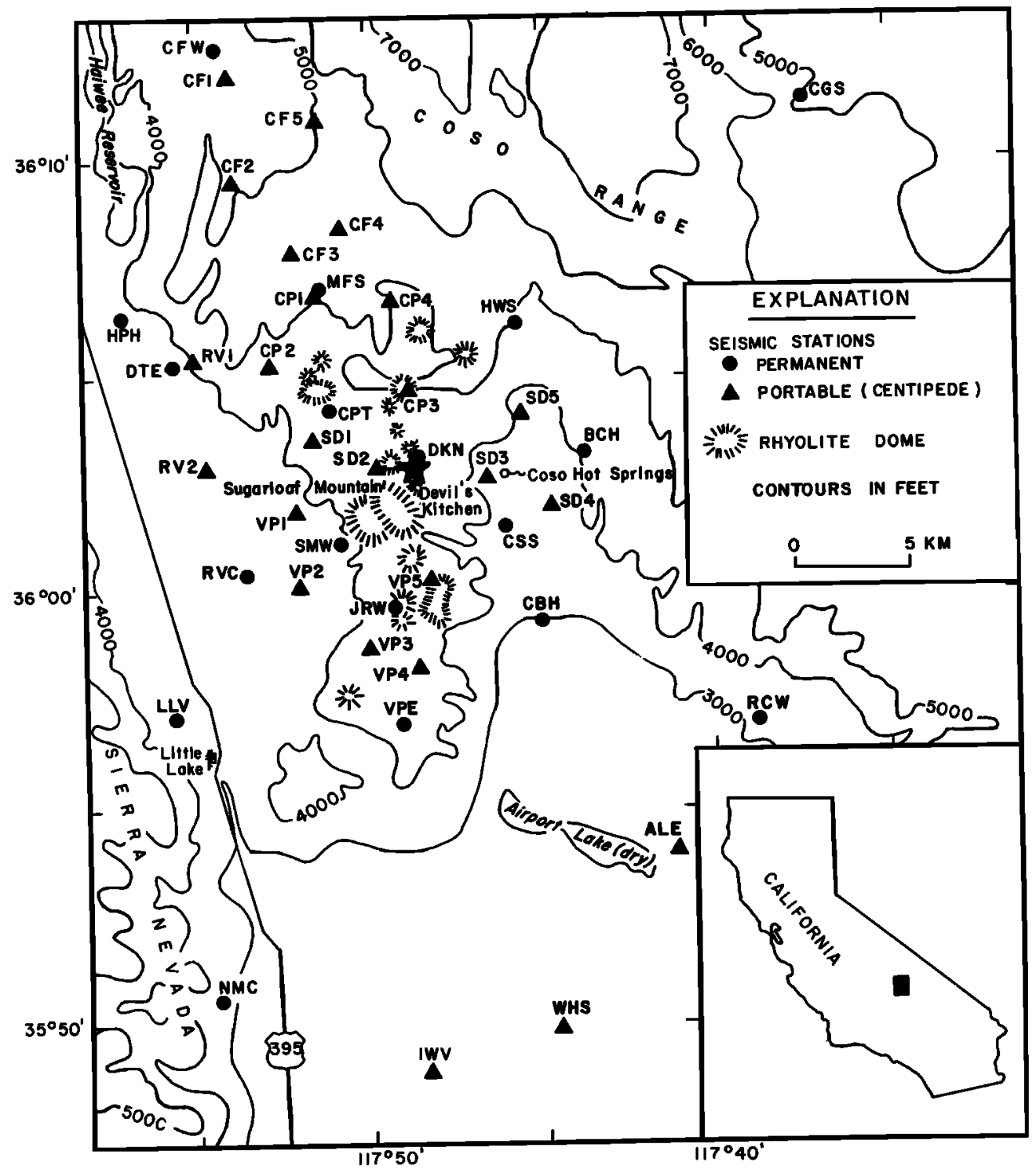

Fig. 1. Map of the Coso geothermal area showing generalized topography, locations of rhyolite domes, and seismograph stations used in this study. Central intersection of block element boundaries used in inversion models (Table 4) is indicated by star in Figures 1-6. Elevation contours in feet; $(1 \mathrm{ft}=0.30 \mathrm{~m})$.

tages of computer-assisted picking over hand processing include a dramatic improvement of timing accuracy, the ability to measure weak arrivals normally considered too small for visual analysis, and a measurement free from operator bias. The precision of the phase correlation time for each seismogram was estimated using the procedure described in the appendix. Timing uncertainties for the seven events analyzed averaged about $0.01 \mathrm{~s}$.

Relative travel time residuals. Measured arrival times $t_{0}$ were cast into a form suitable for further analysis by referencing them to a theoretical arrival time $t_{p}$, forming a travel time residual $r=t_{0}-t_{p}$. To reduce the dependence of the residual data on total travel time and source origin time, relative residuals were formed by removing the mean value of the residuals from the individual reading on an event-by-event basis. The resulting zero mean relative residuals therefore do not depend on a reference station and depend only weakly on the specific set of stations with observations.

Two different methods were used to construct the reference travel time $t_{p}$. Source coordinates reported in the Preliminary
Determination of Epicenters bulletins of the U.S. Geological Survey were used together with the Herrin [1968] travel time table to construct one set of residuals. The second set was prepared for only the Centipede network data by determining the best fitting plane wave to the $t_{0}$ readings for each event, using the method of least squares. The residual to this fitting of the data is the desired relative residual.

The relative residual patterns produced by these two methods are in close agreement (Figure 3). The insensitivity of the relative residuals to the particular reference wave front chosen demonstrates that the residual patterns observed reflect physical structure and are not merely artifacts of the analysis method. In the inversion analysis that follows, the Herrin residuals alone are used.

\section{Evidence for Heterogeneous Structure From INSPECTION OF RELATIVE RESIDUAL DATA}

The 137 events recorded by the permanent network were grouped according to source azimuths, and the mean relative residuals for each azimuthal quadrant were plotted and hand- 
contoured (Figure 2). Inspection of the delay patterns reveals areas of excess delay in the southeast corner of the network for events from the northwest (Figure $2 a$ ) and in the northwest corner of the network for events from the southeast (Figure $2 d$ ). The large width of the source regions contributing to these residual patterns tends to defocus any heterogeneous structure that might be present, and only the most general pattern is revealed. Indeed, the azimuthally widest source region procedures the smoothest pattern (Figure $2 b$ ). Greater resolution of structural heterogeneity is obtained by observing waves from a smaller source region with a denser array. In
Figure 3, contoured relative residuals from the Centipede array are shown for two limited data sets, each representing a single source direction. A similar but more detailed delay pattern is revealed; the wave fronts from the northwest and southeast are delayed at stations southeast and northwest of the center of the array, respectively.

The azimuthal migration of accumulated wave front delays can most easily be explained as a 'delay shadow' produced by a low-velocity zone at depth. Accordingly, a crude model of a possible low-velocity zone can be made by ray tracing. Assuming a uniform upper crustal velocity of $6.0 \mathrm{~km} / \mathrm{s}$, a sphere

TABLE 1. Station Coordinates

\begin{tabular}{|c|c|c|c|c|}
\hline Note & Station & Position & $\begin{array}{c}\text { Elevation, } \\
\text { m }\end{array}$ & $\begin{array}{l}\text { Surface } \\
\text { Element } \\
\text { Solution }\end{array}$ \\
\hline 1 & CF5 & $36^{\circ} 10.95^{\prime} \mathrm{N}, 117^{\circ} 51.35^{\prime} \mathrm{W}$ & 1500 & 0.58 \\
\hline 1 & CF1 & $36^{\circ} 11.84^{\prime} \mathrm{N}, 117^{\circ} 53.78^{\prime} \mathrm{W}$ & 1366 & -0.36 \\
\hline 1 & CF4 & $36^{\circ} 8.46^{\prime} \mathrm{N}, 117^{\circ} 50.67^{\prime} \mathrm{W}$ & 1646 & 1.92 \\
\hline 1 & CF3 & $36^{\circ} 7.89^{\prime} \mathrm{N}, 117^{\circ} 54.22^{\prime} \mathrm{W}$ & 1527 & 2.13 \\
\hline 1 & CF2 & $36^{\circ} 9.48^{\prime} \mathrm{N}, 117^{\circ} 53.75^{\prime} \mathrm{W}$ & 1451 & 2.93 \\
\hline 1 & CP1 & $36^{\circ} 6.94^{\prime} \mathrm{N}, 117^{\circ} 51.34^{\prime} \mathrm{W}$ & 1518 & 1.50 \\
\hline 1 & $\mathrm{CP} 2$ & $36^{\circ} 5.27^{\prime} \mathrm{N}, 117^{\circ} 52.70^{\prime} \mathrm{W}$ & 1320 & 1.12 \\
\hline 1 & CP4 & $36^{\circ} 6.78^{\prime} \mathrm{N}, 117^{\circ} 49.18^{\prime} \mathrm{W}$ & 1522 & -0.78 \\
\hline 1 & CP3 & $36^{\circ} 4.70^{\prime} \mathrm{N}, 117^{\circ} 48.74^{\prime} \mathrm{W}$ & 1562 & 0.54 \\
\hline 1 & SD2 & $36^{\circ} 2.92^{\prime} \mathrm{N}, 117^{\circ} 49.68^{\prime} \mathrm{W}$ & 1268 & -2.07 \\
\hline 1 & SD1 & $36^{\circ} 3.54^{\prime} \mathrm{N}, 117^{\circ} 51.51^{\prime} \mathrm{W}$ & 1268 & -1.71 \\
\hline 1 & SD4 & $36^{\circ} 2.05^{\prime} \mathrm{N}, 117^{\circ} 44.70^{\prime} \mathrm{W}$ & 1097 & -4.64 \\
\hline 1 & SD5 & $36^{\circ} 4.19 \mathrm{~N}, 117^{\circ} 45.57^{\prime} \mathrm{W}$ & 1170 & -1.50 \\
\hline 1 & SD3 & $36^{\circ} 2.69^{\prime} \mathrm{N}, 117^{\circ} 46.55^{\prime} \mathrm{W}$ & 1134 & -4.42 \\
\hline 1 & VPI & $36^{\circ} 1.87^{\prime} \mathrm{N}, 11^{\circ} 51.99^{\prime} \mathrm{W}$ & 1622 & 6.04 \\
\hline 1 & VP2 & $36^{\circ} 0.15^{\prime} \mathrm{N}, 117^{\circ} 51.95^{\prime} \mathrm{W}$ & 1094 & 1.55 \\
\hline 1 & VP5 & $36^{\circ} 0.34^{\prime} \mathrm{N}, 117^{\circ} 48.16^{\prime} \mathrm{W}$ & 1268 & 1.27 \\
\hline 1 & VP3 & $35^{\circ} 58.71^{\prime} \mathrm{N}, 117^{\circ} 49.88^{\prime} \mathrm{W}$ & 1513 & 4.23 \\
\hline 1 & VP4 & $35^{\circ} 58.27^{\prime} \mathrm{N}, 117^{\circ} 48.51^{\prime} \mathrm{W}$ & 1501 & 1.55 \\
\hline 1 & RV2 & $36^{\circ} 2.86^{\prime} \mathrm{N}, 117^{\circ} 54.56^{\prime} \mathrm{W}$ & 1059 & 0.34 \\
\hline 1 & RV1 & $36^{\circ} 5.37^{\prime} \mathrm{N}, 117^{\circ} 54.96^{\prime} \mathrm{W}$ & 1195 & -1.37 \\
\hline 1 & CLR & $35^{\circ} 42.76^{\prime} \mathrm{N}, 117^{\circ} 35.80^{\prime} \mathrm{W}$ & 663 & -4.75 \\
\hline 1 & ALE & $35^{\circ} 54.04^{\prime} \mathrm{N}, 117^{\circ} 41.16^{\prime} \mathrm{W}$ & 732 & \\
\hline 2 & $\mathbf{R C W}$ & $35^{\circ} 57.04^{\prime} \mathrm{N}, 117^{\circ} 38.86^{\prime} \mathrm{W}$ & 945 & \\
\hline 1 & WHS & $35^{\circ} 49.88^{\prime} \mathrm{N}, 117^{\circ} 44.60^{\prime} \mathrm{W}$ & 707 & \\
\hline 2 & HWS & $35^{\circ} 06.30^{\prime} \mathrm{N}, 117^{\circ} 45.67^{\prime} \mathrm{W}$ & 1448 & 7.81 \\
\hline 3 & CBH & $35^{\circ} 59.38^{\prime} \mathrm{N}, 117^{\circ} 45.01^{\prime} \mathrm{W}$ & 884 & -10.51 \\
\hline 2 & VPE & $35^{\circ} 56.98^{\prime} \mathrm{N}, 117^{\circ} 49.02^{\prime} \mathrm{W}$ & 1463 & 4.45 \\
\hline I & IWV & $35^{\circ} 48.85^{\prime} \mathrm{N}, 117^{\circ} 48.31^{\prime} \mathrm{W}$ & 706 & \\
\hline 2 & NMC & $35^{\circ} 50.57^{\prime} \mathrm{N}, 117^{\circ} 54.29^{\prime} \mathrm{W}$ & 951 & \\
\hline 3 & MFS & $36^{\circ} 7.03^{\prime} \mathrm{N}, 117^{\circ} 51.30^{\prime} \mathrm{W}$ & 1524 & 2.76 \\
\hline 4 & JRW & $35^{\circ} 59.70^{\prime} \mathrm{N}, 117^{\circ} 49.20^{\prime} \mathrm{W}$ & 1387 & 5.54 \\
\hline 3 & SMW & $36^{\circ} 1.17^{\prime} \mathrm{N}, 117^{\circ} 50.72^{\prime} \mathrm{W}$ & 1113 & 0.36 \\
\hline 4 & DKN & $36^{\circ} 3.13^{\prime} \mathrm{N}, 117^{\circ} 48.56^{\prime} \mathrm{W}$ & 1341 & -1.25 \\
\hline 4 & RVC & $36^{\circ} 0.47^{\prime} \mathrm{N}, 117^{\circ} 53.42^{\prime} \mathrm{W}$ & 1066 & 2.49 \\
\hline 5 & CPT & $36^{\circ} 4.26 \mathrm{~N}, 117^{\circ} 51.01^{\prime} \mathrm{W}$ & 1494 & -1.84 \\
\hline 8 & DTE & $36^{\circ} 5.82 \mathrm{~N}, 117^{\circ} 55.52^{\prime} \mathrm{W}$ & 1143 & -4.23 \\
\hline 6 & HPH & $36^{\circ} 6.38^{\prime} \mathrm{N}, 117^{\circ} 57.00^{\prime} \mathrm{W}$ & 1160 & \\
\hline 1 & CGS & $36^{\circ} 11.41^{\prime} \mathrm{N}, 117^{\circ} 37.39^{\prime} \mathrm{W}$ & 1676 & 5.99 \\
\hline 5 & CSS & $36^{\circ} 1.58^{\prime} \mathrm{N}, 117^{\circ} 46.01^{\prime} \mathrm{W}$ & 1143 & -1.64 \\
\hline 7 & $\widehat{\mathbf{B C H}}$ & $36^{\circ} 3.28^{\prime} \mathrm{N}, 117^{\circ} 43.74^{\prime} \mathrm{W}$ & 1265 & -3.24 \\
\hline 5 & CFW & $36^{\circ} 12.50^{\prime} \mathrm{N}, 117^{\circ} 54.23^{\prime} \mathrm{W}$ & 1372 & -1.74 \\
\hline 9 & LRS & $36^{\circ} 12.38^{\prime} \mathrm{N}, 117^{\circ} 59.93 \mathrm{~W}$ & 1326 & \\
\hline 8 & LLV & $3^{\circ} 57.13^{\prime} \mathrm{N}, 117^{\circ} 57.13^{\prime} \mathrm{W}$ & 975 & \\
\hline 10 & CLC & $35^{\circ} 49.00 \mathrm{~N}, 117^{\circ} 35.80^{\prime} \mathrm{W}$ & 766 & -2.54 \\
\hline \multicolumn{5}{|c|}{$\begin{array}{l}\text { 1 USGS Centipede system portable station; operated May-June } 1977 . \\
2 \text { USGS permanent network station; operated September } 1975 \text { to present (July 1978). } \\
3 \text { USGS permanent network station; operated September } 1975 \text { to October } 1977 . \\
\text { 4 USGS permanent network station; operated September } 1975 \text { to March } 1977 \text { and July-October } 1977 . \\
\text { 5 USGS permanent network station; operated September } 1975 \text { to March } 1977 \text { and July } 1977 \text { to present } \\
\text { July 1978). } \\
{ }^{6} \text { USGS permanent network station; operated March } 1976 \text { to October } 1977 . \\
{ }^{7} \text { USGS permanent network station; operated September } 1975 \text { to March } 1977 . \\
{ }^{8} \text { USGS permanent network station; operated September } 1975 \text { to March } 1976 . \\
{ }^{9} \text { USGS permanent network station; operated April-June } 1977 . \\
{ }^{10} \text { California Institute of Technology seismograph station. }\end{array}$} \\
\hline
\end{tabular}


Reasenberg et al.: Coso Geothermal ARea

TABLE 2. Teleseismic Events, Permanent Network

\begin{tabular}{|c|c|c|c|c|c|}
\hline Date & Origin Time, UT & Depth, km & Distance, deg & Azimuth, deg & $d T / d \Delta, \mathrm{s} / \mathrm{deg}$ \\
\hline Sept. 28, 1975 & $0356: 5.2$ & 612. & 78 & 238 & 5.3 \\
\hline Sept. 28, 1975 & 0913:58.3 & 500. & 84 & 234 & 4.9 \\
\hline Sept. 30,1975 & $0350: 59.2$ & 135. & 61 & 129 & 6.8 \\
\hline Sept. 30, 1975 & $0828: 12.2$ & 33. & 46 & 310 & 7.9 \\
\hline Oct. 1,1975 & $1801: 6.4$ & 556. & 85 & 234 & 4.8 \\
\hline Oct. 2, 1975 & $1106: 46.5$ & 75. & 70 & 310 & 6.1 \\
\hline Oct. 2, 1975 & $1840: 49.2$ & 617. & 79 & 238 & 5.3 \\
\hline Oct. 3, 1975 & $0953: 22.6$ & 13. & 49 & 310 & 7.6 \\
\hline Oct. 3, 1975 & $1416: 17.1$ & 56. & 89 & 257 & 4.7 \\
\hline Oct. 6,1975 & $0952: 16.8$ & 492. & 85 & 233 & 4.9 \\
\hline Oct. 7,1975 & $0637: 57.4$ & 115. & 87 & 248 & 4.8 \\
\hline Oct. 10,1975 & $0550: 17.3$ & 575. & 82 & 236 & 5.0 \\
\hline Oct. 10, 1975 & $1313: 9.4$ & 96. & 77 & 135 & 5.6 \\
\hline Oct. 11, 1975 & $1435: 15.0$ & 9. & 81 & 231 & 5.3 \\
\hline Oct. 11, 1975 & $1441: 13.6$ & 63. & 22 & 137 & 10.1 \\
\hline Oct. 11, 1975 & $1455: 0.3$ & 33. & 81 & 231 & 5.3 \\
\hline Oct. 13,1975 & $2051: 20.2$ & 35. & 81 & 231 & 5.3 \\
\hline Oct. 13,1975 & $2212: 37.5$ & 33. & 81 & 231 & 5.3 \\
\hline Oct. 16,1975 & $0337: 42.5$ & 33. & 81 & 231 & 5.3 \\
\hline Oct. 17, 1975 & $0159: 30.2$ & 540. & 84 & 236 & 4.9 \\
\hline Oct. 17,1975 & $1612: 30.4$ & 267. & 77 & 235 & 5.5 \\
\hline Oct. 17,1975 & $1939: 12.5$ & 33. & 30 & 326 & 8.9 \\
\hline Oct. 18,1975 & $0859: 56.3$ & 1. & 73 & 3 & 5.9 \\
\hline Oct. 19,1975 & $0743: 23.6$ & 590. & 78 & 238 & 5.3 \\
\hline Oct. 19,1975 & $1218: 5.9$ & 83. & 73 & 132 & 5.9 \\
\hline Oct. 19,1975 & $1449: 56.1$ & 320. & 85 & 293 & 4.9 \\
\hline Oct. 20,1975 & $2225: 29.0$ & 33. & 77 & 238 & 5.7 \\
\hline Oct. 21,1975 & $1159: 57.3$ & 1. & 71 & 2 & 6.1 \\
\hline Oct. 22,1975 & $0510: 42.9$ & 429. & 65 & 314 & 6.4 \\
\hline Oct. 23, 1975 & $0450: 43.1$ & 38. & 72 & 236 & 6.0 \\
\hline Oct. 23, 1975 & $2318: 7.8$ & 52. & 92 & 263 & 4.6 \\
\hline Oct. 28,1975 & $1230: 0.2$ & 19. & 2 & 42 & 14.5 \\
\hline Oct. 28,1975 & $1445: 58.7$ & 28. & 89 & 285 & 4.7 \\
\hline Oct. 29,1975 & $0454: 0.7$ & 35. & 25 & 134 & 9.4 \\
\hline Oct. 29,1975 & $0631: 4.1$ & 214. & 75 & 235 & 5.7 \\
\hline Oct. 30,1975 & $0141: 31.5$ & 59. & 73 & 310 & 5.9 \\
\hline Nov. 1, 1975 & 0117:33.9 & 113. & 88 & 285 & 4.8 \\
\hline Nov. 1, 1975 & $0614: 55.5$ & 424. & 78 & 237 & 5.4 \\
\hline Nov, 1,1975 & $1840: 30.7$ & 33. & 74 & 234 & 5.8 \\
\hline Nov. 3, 1975 & $0522: 10.4$ & 33. & 82 & 156 & 5.2 \\
\hline Nov. 4,1975 & $1205: 56.9$ & 24. & 53 & 315 & 7.3 \\
\hline Nov. 4, 1975 & $1241: 10.0$ & 33. & 56 & 323 & 7.2 \\
\hline Nov. 5,1975 & $0158: 54.4$ & 44. & 48 & 118 & 7.7 \\
\hline Nov. 5, 1975 & $0517: 37.1$ & 33. & 81 & 88 & 5.3 \\
\hline Nov. 5,1975 & $1704: 21.4$ & 12. & 29 & 124 & 8.9 \\
\hline Nov. 6, 1975 & $0106: 42.1$ & 61. & 48 & 311 & 7.7 \\
\hline Nov. 8, 1975 & $1100: 24.5$ & 77. & 85 & 253 & 4.9 \\
\hline Nov. 8, 1975 & $1224: 36.7$ & 574. & 81 & 236 & 5.1 \\
\hline Nov. 9, 1975 & $1530: 5.9$ & 77. & 74 & 132 & 5.9 \\
\hline Nov. 9,1975 & $1755: 29.1$ & 82. & 84 & 288 & 5.0 \\
\hline Nov. 10,1975 & $0443: 8.2$ & 33. & 81 & 158 & 5.3 \\
\hline Nov. 11,1975 & $0425: 32.3$ & 355. & 69 & 313 & 6.1 \\
\hline Nov. 11,1975 & $0854: 18.5$ & 31. & 72 & 309 & 6.0 \\
\hline Nov. 13,1975 & $0254: 1.2$ & 33. & 36 & 315 & 8.6 \\
\hline Nov. 13, 1975 & $1548: 46.0$ & 69. & 61 & 313 & 6.8 \\
\hline Nov. 14, 1975 & 0938:31.8 & 594. & 78 & 238 & 5.3 \\
\hline Nov. 15,1975 & $1528: 30.4$ & 33. & 22 & 138 & 10.2 \\
\hline Nov. 16,1975 & $2123: 5.1$ & 18. & 69 & 311 & 6.3 \\
\hline Nov. 17,1975 & $0645: 47.2$ & 122. & 81 & 140 & 5.3 \\
\hline Nov. 19,1975 & $0446: 10.9$ & 26. & 58 & 9 & 7.0 \\
\hline Nov. 19,1975 & $1106: 27.5$ & 62. & 57 & 316 & 7.1 \\
\hline Nov. 22, 1975 & $0850: 9.1$ & 54. & 42 & 310 & 8.1 \\
\hline Nov. 23,1975 & $0939: 28.1$ & 227. & 88 & 245 & 4.7 \\
\hline Nov. 23,1975 & $2302: 7.4$ & 161. & 75 & 310 & 5.7 \\
\hline Nov. 24,1975 & $0334: 49.0$ & 33. & 75 & 233 & 5.8 \\
\hline Nov. 24,1975 & $2140: 30.8$ & 302. & 84 & 232 & 4.9 \\
\hline Nov. 25,1975 & $1415: 2.1$ & 593. & 81 & 236 & 5.1 \\
\hline Nor. 27,1975 & $0825: 56.3$ & 33. & 66 & 53 & 6.5 \\
\hline Nov. 27,1975 & $1042: 47.7$ & 33. & 76 & 235 & 5.7 \\
\hline Nov. 27,1975 & $2011: 37.7$ & 317. & 85 & 293 & 4.9 \\
\hline Nov. 30,1975 & $0531: 25.7$ & 99. & 44 & 311 & 8.0 \\
\hline Dec. 2, 1975 & $2018: 46.4$ & 137. & 85 & 288 & 5.0 \\
\hline Dec. 3, 1975 & $0546: 40.1$ & 246. & 85 & 252 & 4.9 \\
\hline Dec. 5, 1975 & $1754: 39.6$ & 45. & 36 & 315 & 8.6 \\
\hline
\end{tabular}


TABLE 2. (continued)

\begin{tabular}{|c|c|c|c|c|c|}
\hline Date & Origin Time, UT & Depth, km & Distance, deg & Azimuth, deg & $d T / d \Delta, \mathrm{s} / \mathrm{deg}$ \\
\hline Dec. 5, 1975 & $2014: 18.2$ & 68. & 70 & 310 & 6.2 \\
\hline Dec. 6, 1975 & $2247: 30.4$ & 82. & 75 & 134 & 5.8 \\
\hline Dec. 8, 1975 & $1855: 40.6$ & 54. & 58 & 315 & 7.0 \\
\hline Dec. 9,1975 & $0914: 40.6$ & 33. & 73 & 236 & 5.9 \\
\hline Dec. 9,1975 & $1334: 4.1$ & 635. & 79 & 238 & 5.3 \\
\hline Dec. 11,1975 & $0516: 8.4$ & 50. & 86 & 253 & 4.9 \\
\hline Dec. 15,1975 & $0424: 28.8$ & 200. & 86 & 230 & 4.8 \\
\hline Dec. 19,1975 & $0214: 29.6$ & 33. & 87 & 253 & 4.8 \\
\hline Dec. 21, 1975 & $1054: 17.7$ & 554. & 63 & 316 & 6.5 \\
\hline Dec. 21,1975 & $1751: 4.8$ & 109. & 83 & 291 & 5.1 \\
\hline Dec. 26,1975 & $1556: 38.7$ & 33. & 73 & 235 & 5.9 \\
\hline Jan. 1,1976 & $0129: 39.6$ & 59. & 85 & 230 & 4.9 \\
\hline Jan. 1, 1976 & $0221: 10.6$ & 50. & 86 & 229 & 4.9 \\
\hline Jan. 1, 1976 & $1903: 29.4$ & 63. & 86 & 229 & 4.9 \\
\hline Jan. 2, 1976 & $0410: 14.8$ & 64. & 86 & 229 & 4.9 \\
\hline Jan. 2, 1976 & $0950: 20.6$ & 50. & 86 & 285 & 4.9 \\
\hline Jan. 5, 1976 & $0231: 36.3$ & 95. & 64 & 132 & 6.6 \\
\hline Jan. 6, 1976 & $1928: 36.5$ & 33. & 56 & 317 & 7.2 \\
\hline Jan. 6, 1976 & $2354: 22.2$ & 76. & 70 & 131 & 6.1 \\
\hline Jan. 7, 1976 & $1832: 10.2$ & 58. & 92 & 305 & 4.6 \\
\hline Jan. 9, 1976 & $2354: 35.6$ & 168. & 87 & 248 & 4.8 \\
\hline Jan. 12, 1976 & $0656: 31.3$ & 634. & 81 & 236 & 5.0 \\
\hline Jan. 13, 1976 & $1329: 19.5$ & 33. & 62 & 27 & 6.7 \\
\hline Jan. 14, 1976 & $1530: 4.5$ & 407. & 82 & 304 & 5.1 \\
\hline Jan. 16, 1976 & $1046: 15.1$ & 487. & 85 & 234 & 4.9 \\
\hline Jan. 16,1976 & $1054: 28.0$ & 33. & 90 & 244 & 4.7 \\
\hline Jan. 16, 1976 & $2332: 9.4$ & 51. & 86 & 229 & 4.9 \\
\hline Jan. 18, 1976 & $0446: 24.4$ & 33. & 63 & 9 & 6.6 \\
\hline Jan. 20, 1976 & $1722: 15.2$ & 544. & 80 & 236 & 5.2 \\
\hline Jan. 21, 1976 & $0601: 50.9$ & 33. & 61 & 335 & 6.7 \\
\hline Jan. 21, 1976 & $1022: 49.0$ & 50. & 68 & 309 & 6.3 \\
\hline Jan. 22, 1976 & $1828: 58.3$ & 56. & 92 & 263 & 4.6 \\
\hline Jan. 27, 1976 & $2328: 20.9$ & 394. & 82 & 303 & 5.1 \\
\hline Feb. 5,1976 & $0953: 11.7$ & 98. & 74 & 133 & 5.8 \\
\hline Feb. 5, 1976 & $1713: 12.5$ & 78. & 71 & 309 & 6.1 \\
\hline Feb. 9, 1976 & $2129: 57.1$ & 48. & 17 & 143 & 12.3 \\
\hline Feb. 14, 1976 & $1050: 22.2$ & 548. & 84 & 298 & 4.9 \\
\hline Feb. 18,1976 & $0800: 58.6$ & 39. & 45 & 310 & 7.9 \\
\hline Feb. 28, 1976 & $1627: 9.0$ & 9. & 85 & 148 & 4.9 \\
\hline March 4, 1976 & $0250: 0.5$ & 90. & 87 & 249 & 4.8 \\
\hline March 8, 1976 & $2006: 33.3$ & 72. & 86 & 252 & 4.9 \\
\hline March 13, 1976 & $2144: 41.3$ & 165. & 50 & 114 & 7.5 \\
\hline March 25, 1976 & $2216: 10.6$ & 33. & 43 & 138 & 8.1 \\
\hline March 28, 1976 & $2019: 45.6$ & 33. & 63 & 66 & 6.6 \\
\hline April 4, 1976 & $2238: 29.5$ & 332. & 65 & 314 & 6.4 \\
\hline April 7, 1976 & $0038: 28.0$ & 33. & 78 & 233 & 5.6 \\
\hline April 10, 1976 & $1712: 9.2$ & 560. & 78 & 238 & 5.4 \\
\hline April 11,1976 & $1301: 49.6$ & 545. & 80 & 316 & 5.2 \\
\hline April 11, 1976 & $1303: 35.7$ & 529. & 80 & 316 & 5.2 \\
\hline April 12, 1976 & $0441: 51.4$ & 38. & 40 & 311 & 8.3 \\
\hline April 20, 1976 & $1427: 20.6$ & 30. & 28 & 336 & 8.9 \\
\hline April 24, 1976 & $1105: 15.7$ & 94. & 78 & 138 & 5.5 \\
\hline April 27, 1976 & $1814: 19.0$ & 33. & 25 & 136 & 9.3 \\
\hline May 4, 1976 & $0440: 46.5$ & 33. & 77 & 89 & 5.6 \\
\hline May 5, 1976 & 1637:9.1 & 73. & 74 & 133 & 5.8 \\
\hline May 9, 1976 & $2044: 44.7$ & 34. & 92 & 263 & 4.6 \\
\hline
\end{tabular}

of radius $5 \mathrm{~km}$ buried beneath Devil's Kitchen at $15-\mathrm{km}$ depth, with velocity $5.4 \mathrm{~km} / \mathrm{s}$, could roughly account for the location and amplitude of the observed wave front delays. Such a model, however, is highly nonunique and serves mainly as a guide for formulation of the three-dimensional inversions presented below.

\section{Determination of a Three-Dimensional Velocity STRUCTURE}

Variations in the pattern of relative travel time delays described above present clear evidence for the presence of a lowvelocity body imbedded in the crust beneath the Coso Range. A more complete modeling of these data using the three-di- mensional inversion method of Aki et al. [1977] permits better definition of the body and measurement of the velocity contrast between it and the host rock. The method determines velocity perturbations within a limited volume underlying the seismograph array that minimize the variance of the observed travel time data through solution of a linearized system of equations.

Methodology. The modeling procedure used in this paper closely follows the single-step stochastic inverse solution described by Aki et al. [1977]. An initial model composed of homogeneous plane parallel layers is divided into a grid of right rectangular prisms. The inverse solution determines perturbations in velocity, with respect to the homogeneous start- 
TABLE 3. Teleseismic Events, Centipede System Array

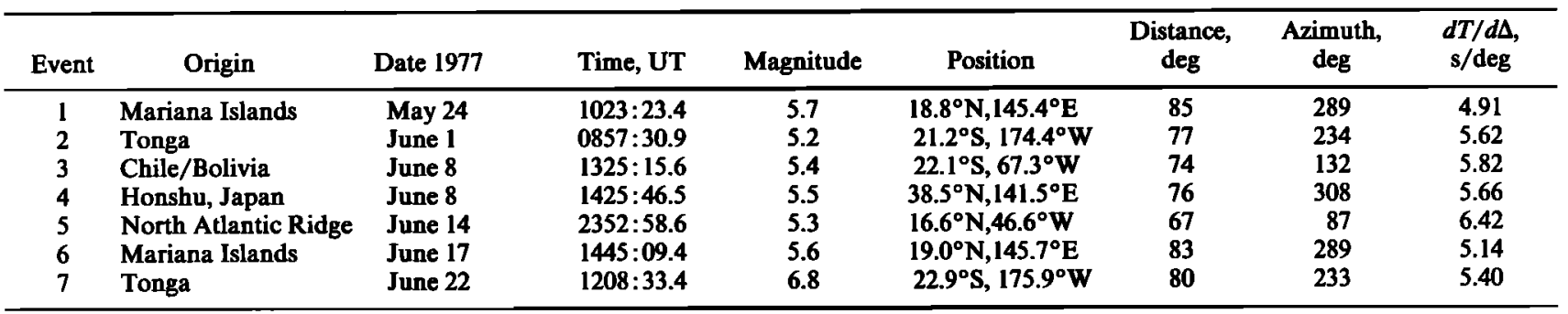

Data are from the U.S. Geological Survey, National Earthquake Information Service. Preliminary Determination of Epicenters.

ing model, for each prism or model element. Ray paths along the reference wave front are traced through the block structure for each source-receiver pair, and the time spent by each ray in each block $a_{i j k}$ is calculated for use in constructing normal equations relating fractional changes in block velocity $m_{k}$ to the zero mean time residuals $r_{i j}$. The $k$ th normal equation is

$$
\sum_{j l}\left(a_{i j k} a_{i j l}-\frac{\bar{a}_{j k} \bar{a}_{j l}}{n_{j}^{2}}\right) m_{l}=-\sum_{v} a_{i j k}\left(r_{i j}-\frac{\bar{r}_{j}}{n_{j}}\right)
$$

where

$$
\begin{gathered}
\sum_{i} a_{j k}=\bar{a}_{j k} \\
\sum_{i} r_{j j}=\bar{r}_{j}
\end{gathered}
$$

Using matrix notation, (1) may be written as

$$
\mathbf{G} \mathbf{m}=\mathbf{d}
$$

where $m$ is a vector containing the yet unknown model perturbations $m_{k}, \mathbf{G}$ is a semidefinite matrix defined by the left side of (1), and $d$ is a vector defined by the right side of (1). The method of damped least squares [Levenberg, 1944; Marquardt, 1963] is used to solve (1), and the solution is given by

$$
\hat{\mathbf{m}}=\left(\mathbf{G}+\theta^{2} I\right)^{-1} \mathbf{d}
$$

where $\hat{m}$ is the damped least squares solution, $\theta^{2}$ is a positive constant (damping parameter), and $I$ is the identity matrix. For (3) the resolution matrix is given by

$$
\mathbf{R}=\left(\mathbf{G}+\boldsymbol{\theta}^{2} \mathbf{I}\right)^{-1} \mathbf{G}
$$

and the covariance matrix by

$$
\mathbf{C}=\sigma_{d}^{2}\left(\mathbf{G}+\boldsymbol{\theta}^{2} \mathbf{I}\right)^{-1} \mathbf{R}
$$

when data errors are uncorrelated and have uniform variance $\sigma_{d}{ }^{2}$. The standard error of the solution is given by

$$
\Delta \hat{m}_{i}=C_{i i}^{1 / 2}
$$

and is bounded by

$$
\Delta \hat{m}_{i} \leq \frac{\sigma_{d}}{\theta}\left[R_{t}\left(1-R_{t i}\right)\right]^{1 / 2} \leq \frac{\sigma_{d}}{2 \theta}
$$

[Ellsworth, 1977].

Selection of a value for the damping parameter $\theta^{2}$ is motivated by $A k i$ et al. [1977], who note that when

$$
\theta^{2}=\sigma_{d}^{2} / \sigma_{m}^{2}
$$

(3) is a special case of the stochastic inverse of Franklin [1970], where $\sigma_{m}$ is the root mean square fluctuation of the true model m.
Solution of the linearized problem defined by (1) produces an image of lateral variations in velocity within each layer of the model. Absolute values of the velocity variations cannot be determined by the method [Aki et al., 1977]. Consequently, the solution within each layer is relative to an unknown mean. Fortunately, precise knowledge of the average vertical velocity profile is not required for the solution to have quantitative value, since the method can tolerate substantial errors in layer velocity. Iterative refinement of the solution would be desirable to help reveal the fine details of the velocity heterogeneities. However, numerical experiments reported by Ellsworth [1977] and Smith et al. [1978] show the linear theory to be remarkably accurate. All solutions reported below are single-step solutions.

Application to Coso. Successful imaging of laterally varying structure requires an appropriate distribution of both sources and receivers. Combination of data from the permanent and Centipede networks provides an ideal data set of azimuthally well distributed source events with travel times measured on a dense grid of receivers. These data allow a horizontal spacing of block model elements of $5 \mathrm{~km}$ (Table 4), which effectively defines the lateral resolution of the model. The height of the blocks is chosen to enhance the vertical resolution. Cubic blocks cannot be adequately resolved by the data owing to the steep angle of incidence of teleseismic $P$ waves in the crust. Vertical resolution can be improved by selecting blocks that are taller than they are wide, since this improves the crossfire of ray paths through the model [Ellsworth and Koyanagi, 1977]. With the exception of the surface layer a height-to-width ratio of 1.5 , for a layer thickness of $7.5 \mathrm{~km}$, is used. This layer thickness provides useful vertical resolution in the crust.

Modeling of the surface layer requires special treatment because ray paths to individual stations do not mix with ray paths from neighboring stations above about $5-\mathrm{km}$ depth. Without loss of generality, each station may then be assigned a unique first-layer element in place of a regular block format for this layer. Inversion of this three-layer model simultaneously determines average velocity variations for the block elements in layers 2 and 3 and surface element solutions (Table 1) for layer 1. Use of these surface element solutions (effectively, angle-of-incidence dependent station corrections) improves the numerical resolution of the underlying layers.

The layered earth model used in computing ray paths is a simplified version of the reversed refraction model determined by C. S. Weaver and A. Walter (unpublished manuscript, 1980). The most extreme mismatch between the approximate layered structure and the measured structure occurs for the model with the thickest first layer (Table 4). Numerical experiments show that the use of a velocity $25 \%$ too low for this layer does not significantly affect the inverse solution. 


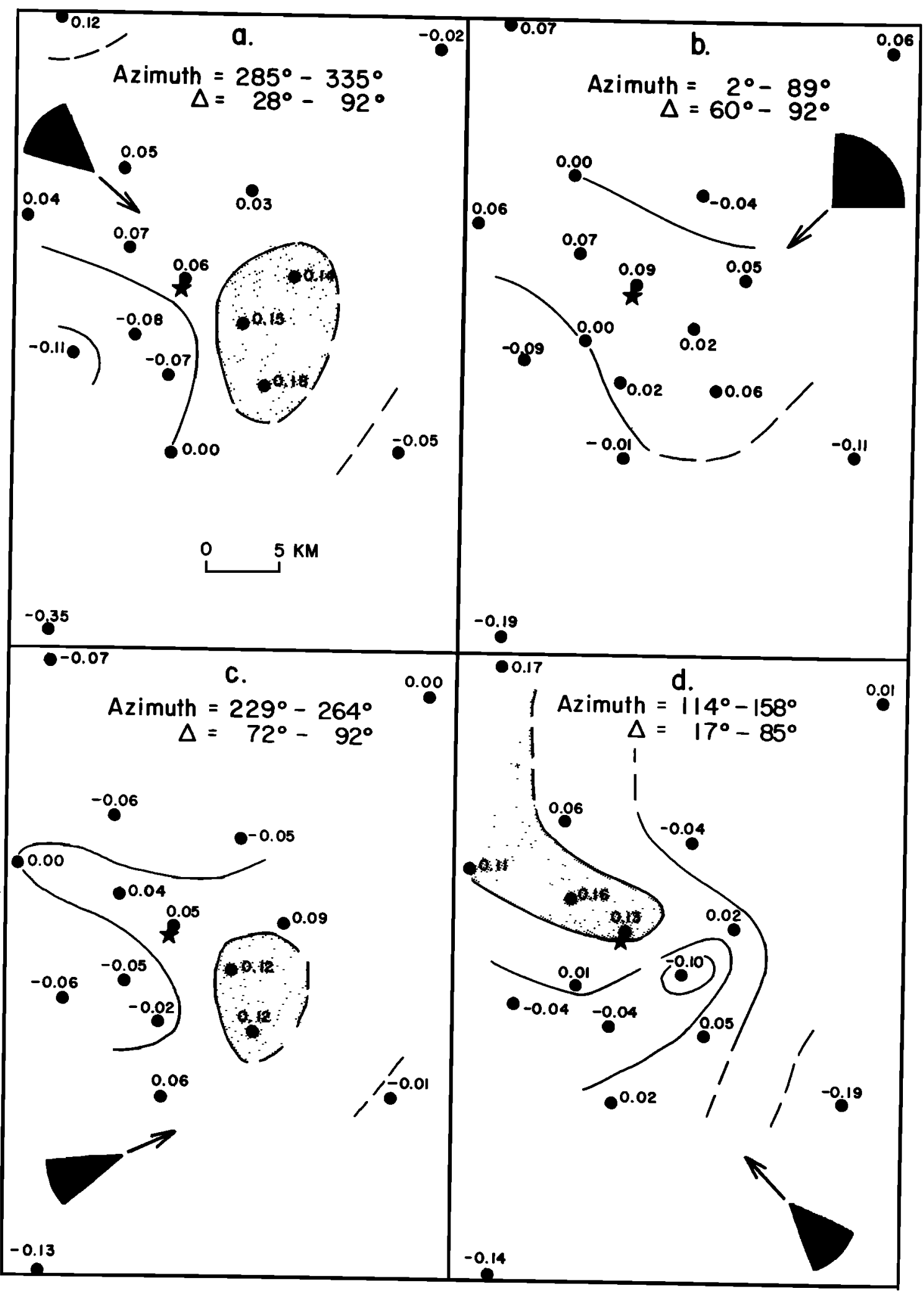

Fig. 2. Relative residual patterns dervied from permanent network data. Shown for each station are mean Herrin residuals for events within four limited source regions indicated. Corresponding data uncertainties average $0.02 \mathrm{~s}$. Contour in-
terval, $0.1 \mathrm{~s}$. Shading covers areas where delay exceeds $0.1 \mathrm{~s}$.

Selection of the proper value for the damping parameter using (7) implies that $\sigma_{m}$ be known. Since $\sigma_{m}$ is initially unknown, a series of model experiments was conducted to establish a range of values for various choices of $\theta$. The results of three experiments (Table 5) indicate that the mean square fluctuation of the crustal velocity beneath the array is about $2.5 \%$, which suggests an ideal value of $\theta^{2}=0.0004 \mathrm{~s}^{2} / \%^{2}$. Table 5 also illustrates the classical trade-off between resolution and modeling error discussed by Backus and Gilbert [1968]. The value of $\theta^{2}=0.001 \mathrm{~s}^{2} / \%^{2}$ adopted for the final 


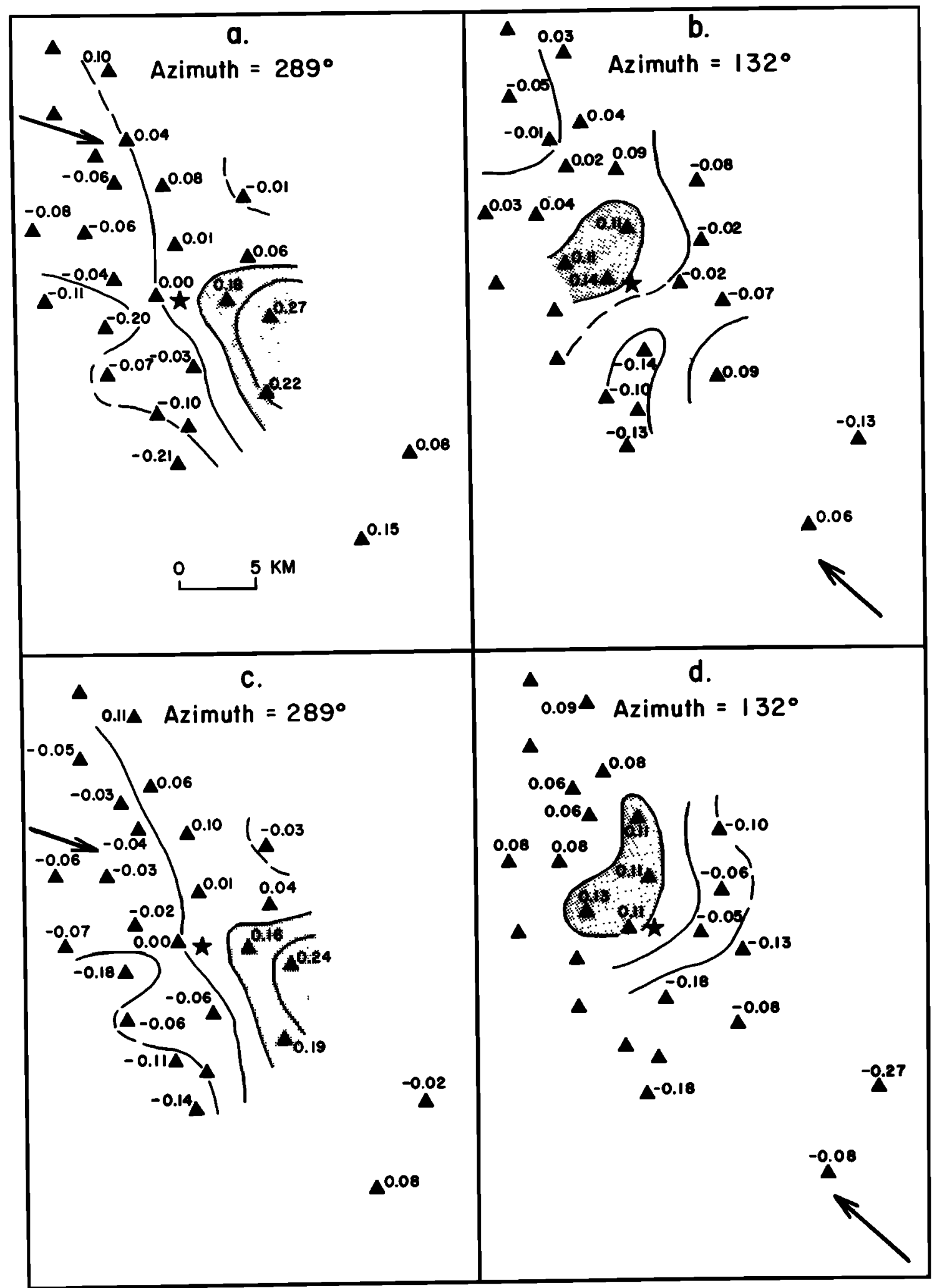

Fig. 3. Relative residual patterns for events from two particular source directions, recorded by Centipede array. Herrin residuals are shown in Figures $3 c$ and $3 d$, least squares fitted plane wave residuals are shown in Figures $3 a$ and $3 b$. Contour interval, $0.1 \mathrm{~s}$.

models discussed below reflects our preference for improved control over standard errors at the expense of a slight degradation in spatial resolution. Explicit examples of model resolutions are discussed below. Using the adopted value for $\theta^{*}$, the depth to which modeling of laterally varying structure is feasible was determined by the $F$ test introduced by $A k i$ et al. [1977] to be 20-25 km (a three-layer model).

Resolution of three-dimensional structure. Application of the inversion method to the Coso network determines a highresolution image of lateral variations in velocity structure be- 
TABLE 4. Layered Velocity Models Used for Inversion Studies

\begin{tabular}{ccccc}
\hline Layer & $\begin{array}{c}\text { P Velocity, } \\
\text { km/s }\end{array}$ & $\begin{array}{c}\text { Thickness, } \\
\text { km }\end{array}$ & $\begin{array}{c}\text { Block } \\
\text { Length, km }\end{array}$ \\
\hline 1 & 4.5 & Model A & 2.5 & \\
2 & 6.0 & 7.5 & 5.0 \\
3 & 6.0 & & 7.5 & 5.0 \\
& & & & \\
1 & 4.5 & & 5.0 & 5.0 \\
2 & 6.0 & & 7.5 & 5.0 \\
3 & 6.0 & & 7.5 & 5.0 \\
& & Model C & & \\
1 & 4.5 & & 7.5 & 5.0 \\
2 & 6.0 & 7.5 & 5.0 \\
3 & 6.0 & 7.5 & 5.0 \\
\hline
\end{tabular}

neath the array (Figure 4). Rapid spatial variations in velocity with spatial wavelengths comparable to those seen in the wave front delay diagrams (Figures 2 and 3) are clearly present. The modeled structure also indicates the continuance of significant lateral heterogeneity through the deepest level modeled.

The inversion results for a single model depend strongly upon the precise configuration of the block elements because the solution for a block represents the average velocity fluctuation in its volume. The influence of the block boundaries on the solution can be reduced by forming the spatial average of two models with block gridwork displaced diagonally by onehalf block length. These smoothed images of lateral heterogeneity are suitable for contouring (Figure 5). The position of the layer boundaries also exerts an artificial influence upon the model. Consequently, three different divisions of the crust into layers are presented (Table 4). Although these models are not independent, they illustrate the vertical transformation of the heterogeneity pattern.

The ensemble of models, considered individually, succeeds in explaining the travel time observations. For example, the solution depicted in Figure 4 reduces the variance of the residuals by $80 \%$, leaving an unmodeled rms residual of $0.047 \mathrm{~s}$. Although the models adequately explain the data using less than $10 \%$ of the available degrees of freedom, the uniqueness and significance of the models must be quantified before a reliable geologic interpretation can be made.

The inherent nonuniqueness of the inverse solution can be studied in the framework of the linearized theory using the resolution matrix defined in (4). Each row of the resolution matrix acts as a filter on the true model $\mathrm{m}$ which is unattainable, yielding the damped least squares solution $\mathbf{m}$ :

$$
\hat{\mathbf{m}}=\mathbf{R} \mathbf{m}
$$

For the model to be well resolved, the rows of $\mathbf{R}$ should act as narrow filters, ideally delta functions, centered on the main diagonal of $\mathbf{R}$. The presence of nonzero elements off the main diagonal quantitatively expresses the smoothing of $\mathbf{m}$ created by the inverse operator in (3).

Study of the resolution matrix for the model in Figure 4 shows that blocks with $R_{u} \geq 0.6$ are adequately resolved by the data. These blocks characteristically underlie the region enclosed by the array. Peripheral blocks are poorly resolved in general and cannot be interpreted reliably. Rows of $\mathbf{R}$ for selected blocks in layer 2 of Figure 4 appear in Figure 6. They show that the solution for these blocks is effectively decoupled from the surface layer. Smoothing between layers 2 and 3 is stronger. However, it is not judged to be strong enough to distort the broad-scale feature of the solution.

The significance of the perturbations determined for each block is estimated using the model standard error $\Delta \hat{m}$. Accepting the residual variance as a measure of the true data variance, (6) gives an upper bound on $\Delta$ m of $0.73 \%$. Accordingly, we adopt $1.5 \%$ as a figure of merit in interpreting the significance of the models.

\section{Discussion}

Low-velocity zone below the geothermal area. The three-dimensional velocity structure beneath the array clearly reveals a central, intense low-velocity body in the middle crust (Figures 4 and 5). The structure has a width of approximately 5 $\mathrm{km}$ and becomes increasingly enlongated in the $\mathrm{N}-\mathrm{S}$, or $\mathrm{N} 25^{\circ} \mathrm{E}$, direction with increasing depth. In each layer except the deepest the $-1 \%$ velocity contour surrounds a single, simply connected zone. The maximum velocity contrast is between 5.6 and $8.4 \%$ and attains its maximum value between 10 and $17.5 \mathrm{~km}$.

Although this ensemble of layered models demonstrates the general properties of the lateral inhomogeneity over the entire depth range modeled, the details of the velocity structure are best seen by considering the unsmoothed solutions for the middepth model (Figures 4 and 6). The solution for the surface layer (Figure 4a) shows below average velocity in the

TABLE 5. Effect of Varying Damping Parameter on Average Performance of Inversion Model

\begin{tabular}{cccc}
\hline \hline $\begin{array}{c}\text { Damping Parameter } \\
\boldsymbol{\theta}^{2}, \mathrm{~s}^{2} / \%^{2}\end{array}$ & Assumed $\sigma_{m} \%$ & $\begin{array}{c}\text { rms Velocity } \\
\text { Perturbation, } \%\end{array}$ & $\begin{array}{c}\text { Mean Standard } \\
\text { Error, } \%\end{array}$ \\
\hline 0.0003 & 3.0 & 2.48 & 0.87 \\
0.0010 & 1.6 & 2.22 & 0.64 \\
0.0030 & 1.0 & 1.95 & 0.44 \\
\hline Theoretical Maximum & Mean & & Data Variance \\
Standard Error, $\dagger$ & Resolution & $\operatorname{Tr}(\boldsymbol{R}) \ddagger$ & 82 \\
\hline 1.61 & 0.83 & 75 & 80 \\
0.89 & 0.69 & 57 & 76 \\
0.52 & 0.51 & 40 & Reduction, $\%$ \\
\hline \hline
\end{tabular}

Values are averages of central 16 elements from layers 2 and 3.

* Standard error of data assumed to be $0.05 \mathrm{~s}$.

†Upper bound on standard error given by (6) when $R_{u i}=0.5$.

$\ddagger$ Trace of resolution matrix for all 102 free parameters (number of singular vectors of $G$ that effectively contribute to the solution). 

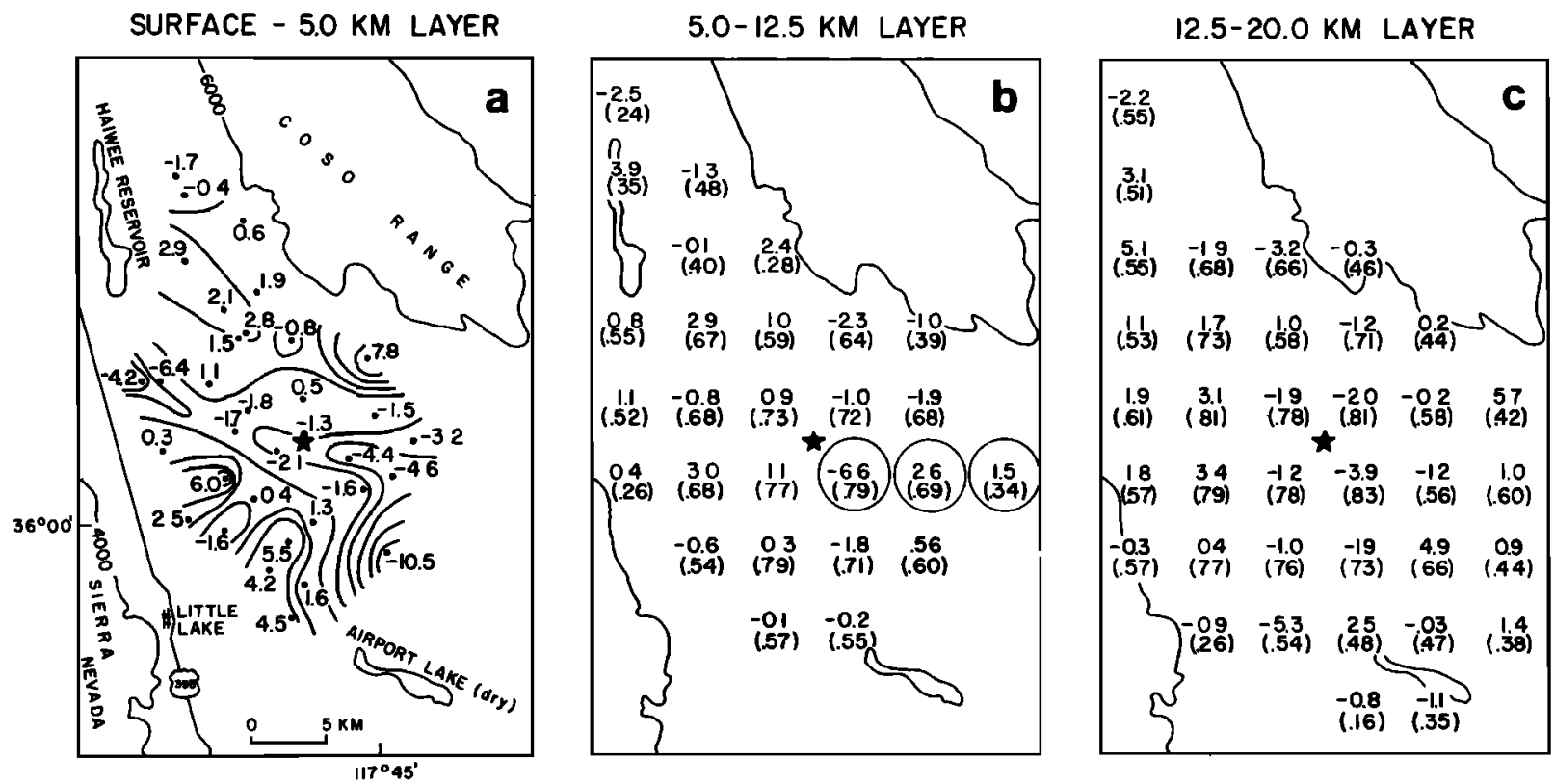

Fig. 4. Unsmoothed inversion solution th for model B (Table 4) showing percent velocity variations, with respect to homogeneous starting model, for model elements. (a) In the surface layer, each model element is associated with an individual seismograph station. Solutions for these elements are shown next to their corresponding stations and listed in Table 1. Areas of low surface velocity (negative solutions) correspond to locations of sedimentary basins (see text). $(b, c)$ Percent velocity variations for blocks in layers 2 and 3 are shown at center of each solution element. In parentheses are the corresponding resolution diagonal elements $\boldsymbol{R}_{t i}$. Circled values indicate blocks for which the full resolution matrices are shown in Figure 6.

sedimentary areas of Cactus Flat (6 km east of Haiwee Reservoir), Upper Cactus Flat ( 9 km north of Sugarloaf Mountain), Rose Valley (south of Haiwee Reservoir), and Coso Basin (7 $\mathrm{km}$ north of Airport Lake). A significant ridge of low velocity oriented approximately east-west crossing the central part of the array is possibly associated with the fractured and altered rock in that area (C. Bacon, personal communication, 1979). The solution for the surface is well decoupled from the layer below it (Figure 6 ) and is most easily explained in terms of low-velocity surficial deposits. Within the well-resolved $\left(R_{i i} \geq\right.$ 0.6) portion of layer 2 (Figure $4 b$ ), significantly low velocity rock is contained in a circular region $5-10 \mathrm{~km}$ in diameter, centered $3 \mathrm{~km}$ southeast of the grid center. The lowest velocity in this layer is attributed to the block located beneath Devil's Kitchen. Within the well-resolved area of the deepest layer (Figure 4c) the low-velocity zone is elongate and oriented approximately N-S, with lateral dimension $10-25 \mathrm{~km}$. The lowest-velocity block in this layer lies directly below the lowestvelocity block in layer 2 . Because of some significant vertical smoothing of the solution between these two blocks (Figure 6), part of the solution for the layer 3 block could be due to the extremely low velocity value in layer 2 .

Partial melt. The observed lateral variations in velocity could arise through several distinct physical mechanisms. Iyer and Stewart [1977] have presented a thorough review summarizing the effects upon compressional velocity of temperature, stress, density, mineral orientation, crack and pore properties, and fluid inclusions (including partial melt). We do not undertake to evaluate each of these possibilities for Coso but rather explore the implications of what we consider the most likely candidate, the presence of partial melt.

Partial melt has been proposed as a possible explanation for low-velocity zones inferred from $\boldsymbol{P}$ wave delays at Long Valley [Steeples and Iyer, 1976b], Yellowstone [Iyer and Stewart, 1977], and The Geysers [Iyer et al., 1979]. If partial melt is present at Coso, it can sufficiently explain the 6-8\% crustal velocity variations observed. Murase and McBirney [1973] have demonstrated that partial melting of basalt, occurring at approximately $800^{\circ} \mathrm{C}$, is capable of reducing compressional velocity by more than this amount.

It is well established that molten rock has recently been present at (or near) the surface of the geothermal area. The thermal history at Coso over the past $4 \mathrm{~m}$.y., as revealed by the geology, is characterized by two distinct periods of volcanism, the more recent of which included the emplacement of the rhyolite domes (Figure 1) between 0.3 and $0.04 \mathrm{~m} . \mathrm{y}$. ago [Duffield et al., 1980]. Estimates of the present physical state of the crust at Coso are suggested by local and regional seismic and teleseismic evidence. The apparent confinement of the local and regional seismicity to the upper 8-10 km [Walter and Weaver, 1980] implies ductile behavior below this depth; this implied ductile behavior suggests that some combination of high temperature, low strain rate, and low fluid pressure exists on a regional scale [Verhoogen et al., 1970; R. Stewart, personnal communication, 1979]. This depth corresponds closely to the depth of the low-velocity zone revealed by the teleseismic arrivals. The lateral location of the low-velocity zone coincides with the area of highest heat flow measurements [Combs, 1980], hot springs, fumaroles, and most recent volcanism [Duffield et al., 1980]. To explain the presence of a localized low-velocity zone within a regionally hot and ductile crust requires an additional mechanism. Local presence of partial melt is suggested by the thermal and geologic evidence and is consistent with seismic evidence.

The direction of the least compressive stress in the Coso geothermal area is determined by fault -plane solutions [Weaver and Hill, 1979; Walter and Weaver, 1980] and by surface faulting [Bacon et al., 1980] to be oriented approximately east-west. Dynamic models for Coso that include partial melting and are consistent with the local stress regime have been 


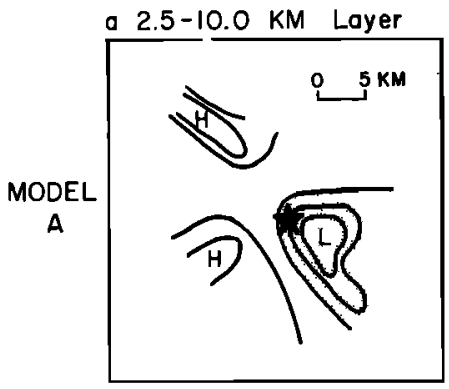

d. 10.0-17.5 KM Layer
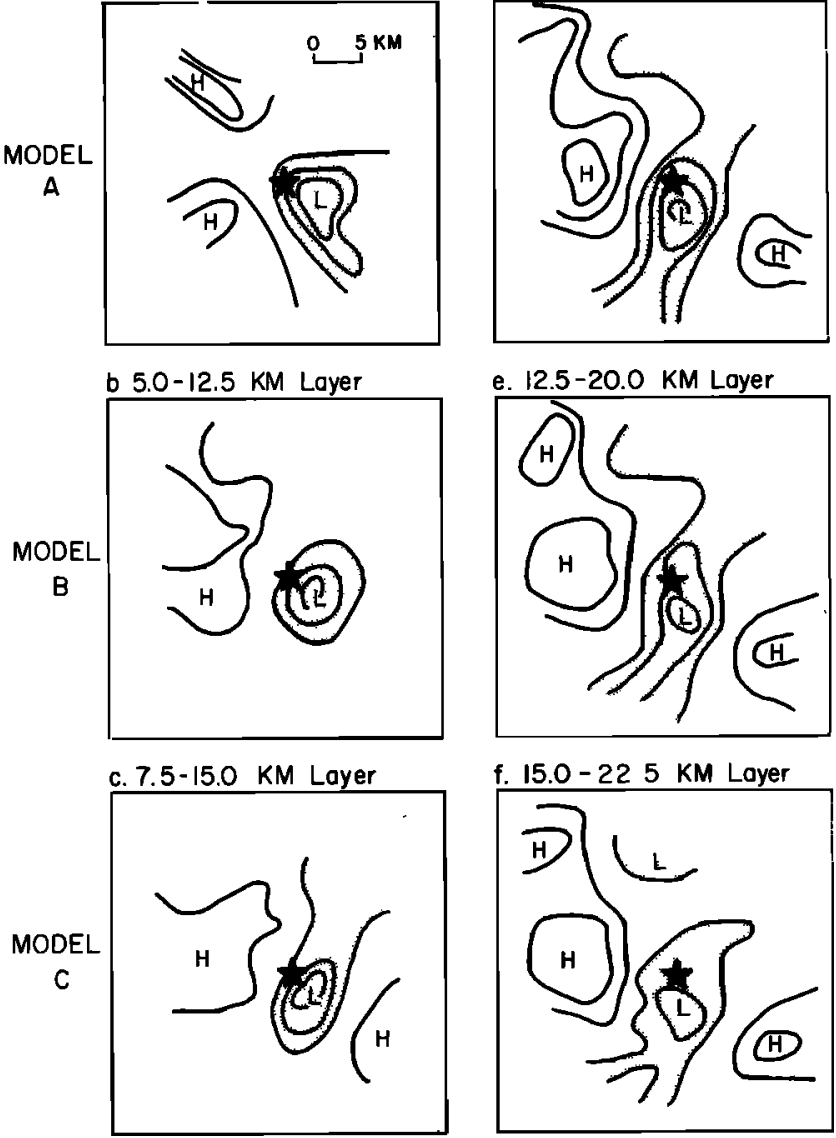

e. 12.5-20.0 KM Loyer

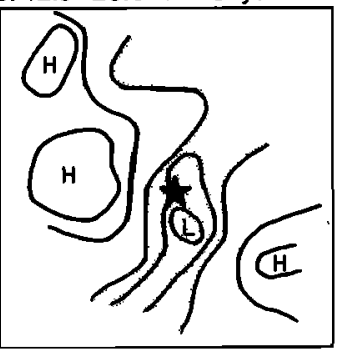

f. 15.0-22 5 KM Loyer

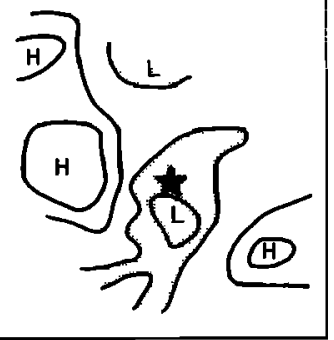

Fig. 5. Smoothed inversion solutions for the second and third layers of the three-block layer divisions modeled (Table 4). Velocity variation contours at $1 \%$ intervals ( $0 \%$ contour omitted) are shown. Highvelocity and low-velocity zones are indicated by $H$ and $L$, respectively. Shaded areas indicate compressional wave velocity $1 \%$ or more slower than average layer velocity. proposed by Weaver and Hill [1979], Bacon et al. [1980], and Duffield et al. [1980]. They suggest that the thermal system which resulted in the deposit of rhyolite at the surface originated with the passive intrusion of basaltic magma into extensional fractures, producing north-south alined, nearly vertical dikes.

Similar models have been proposed by Lachenbruch et al. [1976] for Long Valley and by Thompson and Burke [1974] as a general mechanism for the Basin and Range province. This model is consistent with the evidence from the teleseismic arrivals at Coso. The close coincidence of the surface projection of the low-velocity zone with the area of rhyolite domes (Figure 1) suggests its identification with the proposed rhyolite reservoir and intrusive dike beneath it. The depth and dimensions of the proposed dike-melt system agree with those estimated for the teleseismic low-velocity zone.

\section{Conclusions}

The pattern of relative residuals derived from teleseismic arrivals recorded at the Coso geothermal area reveals an area of excess delay that migrates with changing source azimuth. This migration can most easily be explained as a delay shadow produced by a low-velocity zone at depth. A simple, nonunique model consisting of a 5-km-radius sphere with $10 \%$ lowered velocity buried $15 \mathrm{~km}$ below Devil's Kitchen can roughly account for the amplitude and location of the observed days.

Inversion of the relative residual data for three-dimensional velocity structure determines a high-resolution image of lateral variations in velocity beneath the seismic array. The modeled three-dimensional velocity structure successfully explains the travel time observations by reducing the variance of the residuals approximately $80 \%$.

An intense, low-velocity body is revealed between 5- and 20-km depth under Devil's Kitchen, approximately $5 \mathrm{~km}$ wide on top, becoming increasingly elongated in the N-S, or

PARTS OF RESOLUTION MATRIX
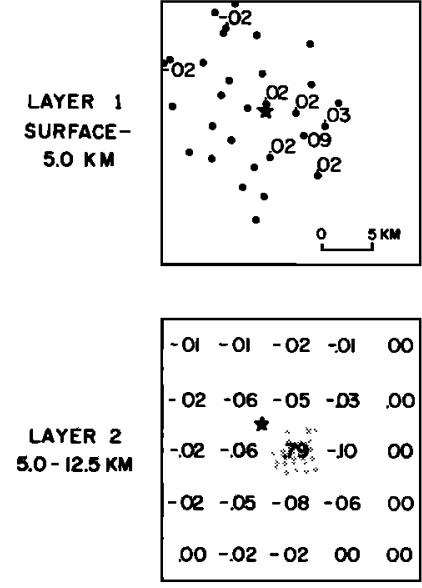

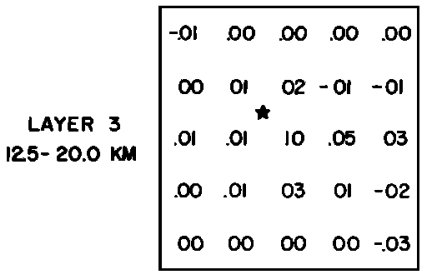
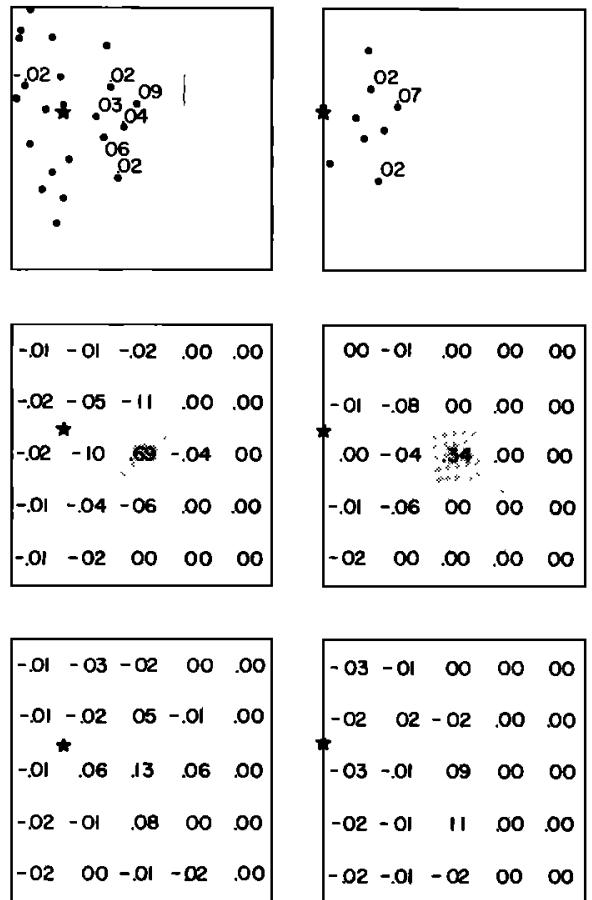

Fig. 6. Selected elements of the resolution matrix for circled block elements in Figure 4. Diagonal element is shaded. Offdiagonal elements in layer 1 smaller than 0.02 are denoted by a dot at the station location. 

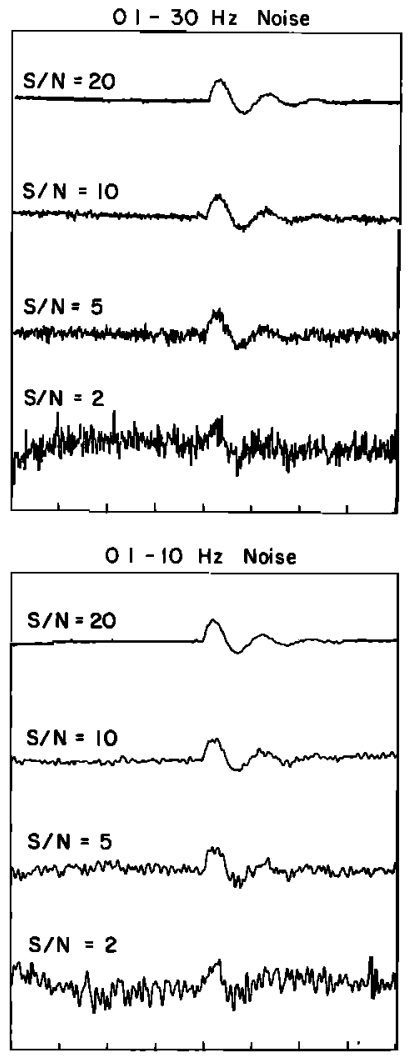

O I - $10 \mathrm{~Hz}$ Noise

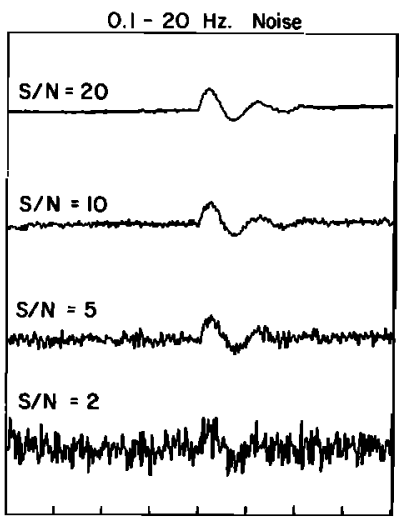

0.I- $50 \mathrm{~Hz}$. Noise

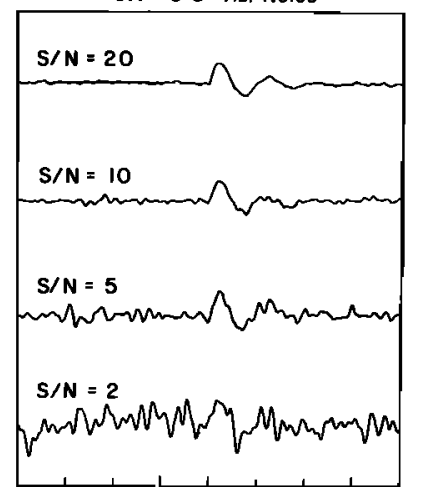

Fig. 7. Examples of synthetic teleseismic $\boldsymbol{P}$ pulses selected from ensembles of traces corresponding to the signal-to-noise ratio and noise bandwidth shown. Tick marks are seconds. Correlation window includes the first $2 \mathrm{~s}$ of the pulse.

TABLE 6. Expected Timing Errors Determined From Synthetic Seismograms

\begin{tabular}{|c|c|c|c|c|}
\hline \multirow[b]{2}{*}{$S / N$} & \multicolumn{4}{|c|}{$S / N$} \\
\hline & 20 & 10 & 5 & 2 \\
\hline \multicolumn{5}{|c|}{ 0.I-to 30-Hz Noise } \\
\hline 20 & 3 & 4 & 8 & 23 \\
\hline 10 & & 7 & 10 & 21 \\
\hline 5 & & & 17 & 33 \\
\hline 2 & & & & 169 \\
\hline \multicolumn{5}{|c|}{ 0.1-10 20-Hz Noise } \\
\hline 20 & 8 & 5 & 11 & 26 \\
\hline 10 & & 9 & 10 & 25 \\
\hline 5 & & & 16 & 34 \\
\hline 2 & & & & 144 \\
\hline \multicolumn{5}{|c|}{ 0.1-to I0-Hz Noise } \\
\hline 20 & 9 & 8 & 16 & 115 \\
\hline 10 & & 14 & 14 & 114 \\
\hline 5 & & & 24 & 71 \\
\hline 2 & & & & 255 \\
\hline \multicolumn{5}{|c|}{ 0.1-to 5-Hz Noise } \\
\hline 20 & 6 & 9 & 21 & 202 \\
\hline 10 & & 10 & 28 & 173 \\
\hline 5 & & & 52 & 203 \\
\hline 2 & & & & 509 \\
\hline
\end{tabular}

Values are expected timing errors (in milliseconds) determined from an ensemble of 71 cross correlations involving traces with signalto-noise $(S / N)$ ratio and noise spectrum indicated. For example, for pairs of traces having $S / N$ ratios of 10 and 2 , each with noise bandwidth of $0.1-30 \mathrm{~Hz}$, the expected timing error is $21 \mathrm{~ms}$. Length of the correlated trace segments is $2 \mathrm{~s}$. Figure 7 shows examples of synthetic seismograms from each ensemble.
$\mathrm{N} 25^{\circ} \mathrm{E}$, direction with increasing depth. Maximum velocity contrast of $8.4 \%$ is attaind between $10-$ and $17.5-\mathrm{km}$ depth.

A plausible explanation for the existence of the low-velocity zone can be made by hypothesizing the presence of partial melt in the middle crust. This hypothesis is consistent with the geologic, thermal, and local seismic evidence. A mechanism for partial melting, proposed by Duffield et al. [1980] and by Bacon et al. [1980] postulates the presence of a N-S alined intrusive dike-melt system under the rhyolite field that coincides with the location and orientation of the low-velocity zone. Agreement between the velocity model obtained from teleseismic arrivals and this dynamic geologic model lends support to both models.

\section{Appendix: estimation of Precision of Timing gy Phase Correlation}

The precision with which the $\boldsymbol{P}$ phases of seismograms from an array can be relatively timed by cross correlation varies with the signal-to-noise ratio and noise spectral content of the seismograms and with the degree to which the $P$ pulse shape remains constant across the array. Because the Centipede array size is small (Figure 1 ), the $P$ pulse shape is similar from station to station, so that the correlation technique is appropriate for the Centipede data. Estimates of timing precision for the Centipede data were obtained statistically by crosscorrelating pairs of traces from ensembles of synthetic seismograms. Each synthetic seismogram was composed of a simple function resembling a teleseismic $\boldsymbol{P}$ pulse to which was added a unique sample of stationary, band-limited Gaussian noise. Each ensemble, consisting of 71 such traces, was characterized by a particular signal-to-noise ratio and noise spectrum (Figure 7). Since the synthetic pulse function is identical in all traces (only the noise portion varied), the expected time lag between any two synthetic traces is zero. The cross correlation of all traces in an ensemble results in a distribution of estimates of lag between traces. The mean of the distribution tends to zero. The standard deviation provides a chi squared estimator of the expected error (due to noise) in the lag determined by the cross correlation. For each pair of ensembles corresponding to a particular combination of $S / N$ ratio and noise spectrum the expected error estimate is shown in Table 6. These error estimates were applied to the recorded data by visually matching each recorded trace with the synthetic trace most closley resembling it (Figure 7) and adopting the corresponding synthetic trace error estimate. The resulting estimates of timing precision from the Centipede data range from 4 to $8 \mathrm{~ms}$ for the best events to $32 \mathrm{~ms}$ for the weakest arrivals.

Acknowledgments. We wish to thank Ed Criley, Bob Cessaro, and Steve Wegener, who obtained the field data used in this study. We are grateful to Craig Weaver, H. M. Iyer, Charlie Bacon, Roger Stewart, Dave Oppenheimer, Keiiti Aki, and John Savino for their stimulating comments and suggestions. We thank Roger Stewart and Dave Oppenheimer for their critical reviews of the manuscript. We also thank Donna Barton, Richard Buszka, and Nancy Tamamian for their valuable assistance in preparing the manuscript and figures.

\section{REFERENCES}

Aki, K., A. Christoffersson, and E. Husebye, Determination of the three-dimensional seismic structure of the lithosphere, J. Geophys. Res., 82, 277-296, 1977.

Backus, G. E., and J. F. Gilbert, The resolving power of gross earth data, Geophys. J. Roy. Astron. Soc., 16, 169-205, 1968.

Bacon, C. R., W. A. Duffield, and K. Nakamura, Distribution of Quatemary rhyolite domes of the Coso Range, California: Implications 
for extent of the geothermal anomaly, J. Geophys. Res., 85 , this issue, 1980.

Bufe, C. G., F. W. Lester, K. L. Meagher, and R. L. Wesson, Catalog of earthquakes along the San Andreas fault system in central California, April-June 1973, Open File Rep. 75-125, U.S. Geol. Surv., Menlo Park, Calif., 1975.

Combs, J., Heat flow in the Coso geothermal area, Inyo County, California, J. Geophys. Res., 85, this issue, 1980.

Duffield, W. A., C. R. Bacon, and G. B. Dalrymple, Late Cenozoic volcanism, geochronology and structure of the Coso Range, Inyo County, California, J. Geophys. Res., 85, this issue, 1980.

Ellsworth, W. L., Three dimensional structure of the crust and mantle beneath the island of Hawaii, Ph.D. thesis, 327 pp., Mass. Inst. of Technol., Cambridge, 1977.

Ellsworth, W. L., and R. Y. Koyanagi, Three-dimensional crust and mantle structure of Kilauea volcano, Hawaii, J. Geophys. Res., 82, 5379-5394, 1977.

Franklin, J., Well posed stochastic extensions of ill-posed linear problems, J. Math. Anal. Appl., 21, 682-716, 1970.

Herrin, E., 1968 seismological tables for $P$ phases, Bull. Seismol. Soc. Amer., 58, 1193-1239, 1968.

Iyer, H. M., Anomalous delays of teleseismic $P$-waves in Yellowstone National Park, Nature, 253, 425-427, 1975.

Iyer, H. M., Deep structure under Yellowstone National Park, U.S.A., A continental 'hot spot', Tectonophysics, 56, 165-197, 1979.

Iyer, $\overline{\mathbf{H}}$. M., and R. M. STtewart, Teleseismic technique to locate magma in the crust and upper mantle, Bull. 96, Oreg. Dep. of Geol. and Miner. Ind., Portland, 1977.

Iyer, H. M., D. H. Oppenheimer, and T. Hitchcock, Large teleseismic $\boldsymbol{P}$-wave delays in The Geysers-Clear Lake geothermal area, California, Science, 204, 495-497, 1979.

Lachenbruch, A. H., J. H. Sass, R. J. Munroe, and T. H. Moses, Jr., Geothermal setting and simple heat conduction models for the Long Valley caldera, J. Geophys. Res., 81, 769-784, 1976.

Levenberg, $K$., A method for the solution of certain non-linear problems in least squares, Quart. Appl. Math., 2, 164-168, 1944.

Marquardt, D. W., An algorithm for least-squares estimation of nonlinear parameters, J. Soc. Indust. Appl. Math., 11, 431-441, 1963.

Murase, T., and A. R. McBirney, Properties of some common igneous rocks and their melts at high temperatures, Geol. Soc. Amer. Bull., 84, 3563-3592, 1973.

Press, F., and S. Biehler, Inferences on crustal velocities and densities from $P$ wave delays and gravity anomalies, $J$. Geophys. Res., 67, 2979-2995, 1964.

Reasenberg, P., The Centipede seismic recording system, Open File Rep. 77-315, U.S. Geol. Surv., Menlo Park, Calif., 1977.

Reasenberg, P., Program Array: An interactive seismic array processing program for use with data sets established by program Evcon, Open File Rep. 78-201, U.S. Geol. Surv., Menlo Park, Calif., 1978.

Smith, M. L., B. R. Julian, E. R. Engdahl, D. Gubbins, and R. Gross, Linearized inversion of travel-times for three-dimensional earth structure (abstract), Eos Trans. AGU, 59, 1130, 1978.

Steeples, D. W., and H. M. Iyer, Teleseismic $\boldsymbol{P}$-wave delays in geothermal exploration, in Proceedings of the Second United Nations Symposium on the Development and Use of Geothermal Resources, vol. 2, pp. 1199-1206, U.S. Government Printing Office, Washington, D. C., $1976 a$.

Steeples, D. W., and H. M. Iyer, Low-velocity zone under Long Valley as determined from teleseismic events, J. Geophys. Res., 81, 849$860,1976 b$.

Thompson, G. A., and D. B. Burke, Regional geophysics of the Basin and Range province, Annu. Rev. Earth Planet. Sci, 2, 213-238, 1974.

Verhoogen, J., F. S. Turner, L. E. Weiss, and C. Wahraftig, The Earth, an Introduction to Physical Geology, pp. 456-466, Holt, Rinehart and Winston, New York, 1970.

Walter, A., and C. S. Weaver, Seismicity of the Coso Range, California, J. Geophys. Res., 85, this issue, 1980.

Weaver, C. S., and D. P. Hill, Earthquake swarms and local crustal spreading along major strike-slip faults in California, Pure Appl. Geophys., II7, 51-66, 1979.

Zandt, G., Study of three-dimensional heterogeneity beneath seismic arrays in central California and Yellowstone, Wyoming, Ph.D. thesis, Mass. Inst. of Technol., Cambridge, 1978.

(Received March 5, 1979;
revised April 17, 1979;

accepted April 30, 1979.) 